\title{
Sistem Informasi Penjualan Obat Pertanian Berbasis Web pada Toko BUTANI Blora
}

\author{
Erni Damayanti 1, Rini Rubhyanti 2, Arsito Ari K ${ }^{3}$, Iman Saufik ${ }^{4}$ \\ 123 Sekolah Tinggi Elektronika dan Komputer Semarang
}

\begin{abstract}
This information system discusses the sale of goods, this research was carried out at the BUTANI store Blora is an entrepreneur engaged in the sale of agricultural drugs including agricultural medicines, agricultural fertilizers, agricultural equipment. Problems that are often faced by BUTANI Blora stores are the recording of sales transactions that are still manual, the difficulty in calculating the final value of sales of goods, recording sales transactions that require accuracy and accuracy in calculating, because among others the recording and calculation of the amount of an item currently still uses a system that has not orderly, so there is often excess or lack of stock, it will have an impact on the service needs of consumers who are not selling. A web-based agricultural drug sales information system is also needed in companies to record sales transactions and to make sales reports. To build this information system using the PHP programming language with a MySQL database, this application was created to make it easier to record sales transactions and make sales reports. With the existence of a sales information system the company is expected to be able to assist management in recording sales transactions, be able to know the stock of goods, and reports needed.
\end{abstract}

Keyword: information system, mysql, php, webserver

\begin{abstract}
Abstrak
Sistem Informasi ini membahas mengenai penjualan barang, penelitian ini dilakukan pada toko BUTANI Blora adalah sebuah wirausaha yang bergerak dibidang penjualan obat pertanian antar lain obat-obatan pertanian, pupuk pertanian, peralatan pertanian. Masalah yang sering dihadapi toko BUTANI Blora adalah pencatatan transaksi penjualan yang masih manual, sulitnya dalam perhitungan nilai akhir penjualan barang, pencatatan transaksi penjualan yang memerlukan ketelitian dan ketepatan dalam menghitung, dikarenakan antara lain pencatatan dan perhitungan jumlah suatu barang saat ini masih menggunakan sistem yang belum tertata, sehingga sering terjadi kelebihan atau kekurangan stok, hal tersebut akan berdampak pada pelayanan kebutuhan konsumen yang kurang laku. Sistem informasi penjualan obat pertanian berbasis web juga sangat dibutuhkan dalam perusahaan untuk mencatat transaksi penjualan dan untuk membuat laporan penjualan. Untuk membangun sistem informasi tersebut menggunakan bahasa pemrograman PHP dengan database $M y S Q L$, aplikasi ini dibuat untuk mempermudah mencatat transaksi penjualan dan membat laporan penjualan. Dengan adanya sistem informasi penjualan diharapkan perusahaan dapat membantu manajemen dalam melakukan pencatatan transaksi penjualan, dapat mengetahui stok barang, dan laporan-laporan yang dibutuhkan.
\end{abstract}

Kata Kunci : Sistem Informasi,mysql, php, webserver

ISSN 2715-0143 (online) ISSN 2714-9048 (print)

http://journal.walisongo.ac.id/index.php/jit/index

WJIT : Walisongo Journal of Information Technology - Vol.1 No. 2 (2019) 


\subsection{LATAR BELAKANG}

Melihat perkembangan teknologi komputer/informasi sudah maju di bidang pendidikan, pemerintahan, dan ekonomi, mengakibatkan teknologi ini dapat dimanfaatkan oleh manusia untuk meningkatkan dan membantu kegiatan rutinitas termasuk di dalamnya kegiatan bisnis. Teknologi komputer informasi dunia menuntut setiap perusahaan untuk memiliki basis data. Sistem basis data ini digunakan untuk menyimpan setiap transaksi sehingga membantu kelancaran proses dan menghasilkan informasi yang berkualitas. Sistem basis data berbasis web merupakan sebuah media yang dapat dipergunakan untuk mengelola data, laporan, serta memudahkan perusahaan dalam memberikan informasi. Sistem basis data berbasis web ini akan meningkatkan pelayanan sebuah perusahaan karena mampu menyimpan dan mengelola data secara efektif dan up to date.

Toko BUTANI Blora adalah sebuah usaha yang bergerak di bidang penjualan obat pertanian, berdiri sejak 2014 dan beralamat di Jalan Gatot Subroto km. 3 Setro Tunjungan Blora, yang merupakan cabang dari Toko BUTANI Blora beralamatkan Ds. Tempur Kec. Kunduran Kab. Blora. Didalam Toko BUTANI Blora terdapat 9 karyawan terdiri dari : 1 pemilik toko, 1 administrasi, 1 kasir, 4 bagian penjualan, 2 kuli angkut.

Toko BUTANI Blora berusaha memenuhi kebutuhan konsumen dengan memperlengkap jenis barang yang dijual. Namun dalam menjalankan usahanya, pencatatan transaksi penjualan masih dicatat dibuku. Sehingga membuat transaksi pembayaran dikasir lebih lama. Untuk melihat stok barang yang ada di dalam toko, kayawan harus menghitung stok barang secara langsung, sehingga membuat karyawan harus mencari dan melihat stok yang ada di dalam persediaan barang dan membuat karyawan kesulitan untuk mengecek jumlah stok barang yang tersedia. Pencatatan yang dilakukan ini memungkinkan terjadinya kesalahan dalam memperbarui catatan data barang atau mencatat transaksi penjualan kedalam buku besar. Hal ini dapat menimbulkan kesalah pahaman dengan pemilik toko BUTANI. Dan toko BUTANI memiliki beberapa cabang di daerah BLORA.

Berdasarkan masalah di atas penulis memberikan salah satu solusi sistem informasi penjualan obat pertanian berbasis website pada toko BUTANI Blora pada bagian kasir, admin dan pemilik toko, sehingga pemilik bisa melihat dan memantau transaksi penjualan pada semua cabang toko BUTANI BLORA. Penelitian ini merancang sebuah aplikasi yang mampu mengolah, menghitung transaksi penjualan, mengetahui stok barang dan membuat laporan penjualan. Melalui sistem informasi berbasis website ini dapat memberikan keunggulan untuk mengetahui proses transaksi dan pembuatan laporan. Hal ini diperlukan agar perkembangan toko BUTANI Blora dapat terpantau secara terperinci, sehingga pembuatan laporan lebih tepat. Sistem informasi 
penjualan yang berbasis Web juga sangat dibutuhkan dalam perusahaan ini untuk membantu divisi kasir, admin dan pemilik toko dalam mengambil keputusan. Untuk membangun sistem informasitersebut menggunakan bahasa pemrograman PHP, dengan menggunakan aplikasi Xampp, dan serta menggunakan databaseMySQL.Dengan adanya sistem informasi penjualan ini diharapkan toko BUTANI dapat melaksanakan perencanaan, pengadaan dan pengawasan penjualan barang dengan baik, dipermudah dalam hal waktu selain itu juga dapat menghasilkan laporan yang akurat, tepat dan cepat.

\subsection{IDENTIFIKASI MASALAH}

Toko BUTANI Blora masih menggunakan pencatatan transaksi penjualan dengan buku dalam pencatatan transaksi penjualan, laporan stok barang dan laporan penjualan yang dilakukan memungkinkan terjadinya kesalahan pencatatan, dan dapat menimbulkan kesalahpahaman.

\subsection{PERUMUSAN MASALAH}

Bagaimana membuat sistem informasi pencatatan transaksi penjualan yang tidak perlu dicatat dibuku?

\subsection{PEMBATASAN MASALAH}

Penginputan adalah data transaksi penjualan, lalu 4 diproses menghasilkan laporan stok barang, laporan penjualan dan laporan laba rugi.

\subsection{TUJUAN PENELITIAN}

Membuat sistem informasi penjualan yang dapat membantu transaksi penjualan dengan baik dan cepat pada toko BUTANI Blora.

\subsection{MANFAAT PENELITIN}

Manfaat Teoritis

Memberikan manfaat bagi pengembangan ilmu komputer terutama dalam teori rekayasa

Perangkat lunak dan ilmu ekonomi sebagai sumber referensi yang dapat memberikan informasi pengetahuan pada pihak-pihak yang akan melakukan penelitian lebih lanjut mengenai permasalahan ini dan dapat bermanfaat dimana program tersebut dapat digunakan pada toko BUTANI Blora.

Manfaat Praktisi

Bagi Penulis Dapat mengambengkan pengetahuan yang selama ini hanya di dapat secara teoritis untuk diterapkan dalam praktek nyata.

Bagi Akademik Bahan perbendaharaan perpustakaan dan studi banding

bagi mahasiswa di masa yang akan datangdan dapat dijadikan sebagai tolak ukur keberhasilan akademik dalam memberikan bekal kepada mahasiswa untuk terjun ke masyarakat.

Bagi Instansi Menyederhanakan sistem kerja terkomputer yang sekarang dengan sistem kerja yang terprogram serta meningkatkan tingkat ketelitian dan memperoleh informasi yang dibutuhkan secara tepat dan cepat sehingga dapat menunjang proses pengambilan keputusan sehingga membantukelancaran operasi kerja. 


\subsection{Deskripsi Teoritik}

2.1.1 Sistem

Sekelompok unsur yang erat hubungannya satu dengan yang lain, yang berfungsi bersama-sama untuk mencapai tujuan tertentu (Sutabiri, 2012)

2.1.2 Informasi

Informasi adalah data yang diolah menjadi bentuk lebih bergunadan lebih berarti bagi yang menerimanya (Yakub, 2012)

2.1.3 Pengertian Sistem Informasi

Sistem informasi adalah suatu sistem didalam suatu organisasi yang mempertemukan kebututuhan pengolahan transaksi harian yang mendukung organisasi yang bersifat manajerial dengan kegiatan strategi dari suatu organisasi untuk dapat menyediakan laporan-laporan yang diperlukan oleh pihak luar tertentu (Sutabiri, 2012)

21.4 Pengertian Penjualan

Penjualan tunai adalah apabila pembeli sudah memilih barang yang akan dibeli, pembeli diharuskan membayarke bagian kas Narko(2008)

2.1.5 Pengertian Sistem Informasi Penjualan

Penjualan tunai merupakan penjualan dengan mengambil barang dari suplierdan langsung dikirim ke customer secara pembayaran langsung dengan menggunakan uang tunai. Sistem penjualan tunai pada umumnya didasarkan pada asumsi bahwa pembeli akan mengambil barang setelah harga barang dibayar ke kasir(Mulyadi, 2008)

2.16 Website

Website merupakan fasilitas internet yang menghubungkan dokumen dalam lingkup lokal maupun jarak jauh. Dokumen pada website disebut dengan webpage dan link dalam website memungkinkan pengguna bisaberpndah dari satu page ke page lain (hypertext), baik diantara page yang disimpan dalam server yang sama maupun server diseluruh dunia.Pages dapat diakses dan dibaca melalu browser seperti Netscape Navigator, Internet Explorer, Mozila Firefox, Goggle Chrome dan aplikasi browser lainya (Hakim, Lukmanul, Uus, 2004)

\subsubsection{PHPMyAdmin}

PHPMyAdmin adalah tools yang dapat digunakan dengan mudah untuk memanajemen database MySQL secara visual dan Server MySQL, sehingga kita tidak perlu lagi harus menulis query SQL setiap akan melakukan perintah operasi database. Toolsini cukup populer, anda dapat mendapatkan fasilitas ini ketika mengistal paket triad phpMyAdmin, karena termasuk dalam XAMPP yang sudah di install (Nugroho, 2003)

\subsubsection{Pengertian Prototyping}

Prototyping adalah bentuk dasar atau model awal dari suatu sistem atau bagian dari suatu sistem. Setelah dioperasikan, prototype ditingkatkan terus sesuai dengan kebutuhan pemakai sistem yang juga meningkat (Jogiyanto, 2003)

2.1.9 Pengertian Flow of Diagram (Flowchart)

Adalah bagan-bagan yang mempunyai arus yang menggambarkan langkah-langkah penyelesaian suatu masalah (AlBahra, 2005)

2.1.10 Data Flow Diagram (DFD) 
Terdapat empt unsur yang digunakan dalam menggambarkan DFD, yaitu sumber dan tujuan data (terminator), arus data, proses tempat penyimpanan data (McLeod, Scell, 2007)

2.1.11 EntityRelation Diagram (ERD) ERD merupakan diagram yang menggambarkan hubungan atar entity didalam database sebagai entity dan relasi. Selain itu, ERD digunakan untuk memperlihatkan hubungan atar data yang ada di DFD. (MecLeod, Scell, 2017)

\subsubsection{Multi User}

Multiuser adalah suatu sistem dimana lebih dari satu user Menggunakan secara bersama satu atau lebih perangkat keras, piranti unak dan data informasi, oran atau prosedur melalui Masing masing Komputer atau workstation (Yakub, 2012).

\subsubsection{Normalisasi}

Menurut Al-Bahra Bin Ladjamudin dalam bukunya yang berjudul Analisis dan Desain Sistem Informasi adalah suatu proses memperbaiki membangun dengan modal data relational, dan secara umu lebih tepat dikoreksikan dengan model data logika (Al-Bahra, 2005)

2.2 Kajian Penelitian yang Relevan 1. Yoahan ArumWidati(2015) dalam jurnal ilmiah yang berjudul Sistem Informasi Penjualan dan Penilaian Batu Muliah Berabasi Web Sentra Industri UD. Sony Permata Pacitan, memberi kesimpulan bahwa sistem penjualan berbasis web sudah dapat dibuat menggunakan bahasi pemrograman PHP dan databse MySQL, sehingga penulis dapat menyimpulkan beberapa hal diantara lain: Pembuatan website dapat membantu UD. Sony Permata menyampaikan informasi tentang batu mulia dan memeberikan layanan pemesanan secara online. Pembuatan website dapat mempermudah konsumen dalam mendapatkan informasi batu mulia.Pembuatan website mempermudah konsumen dalam melakukan ransaksi pembelian secara online. Pembuatan website mempermudah konsumen dalam memilih batu yang akan dibeli dengan cara melakukan perbandingan produk dan penilaian berdasarkan kriteria.

2. Sandy Kosasi (2016), dalam jurnal yang berjudul perancangan sistem informasi penjualan berbasis web dalam memarsarkan mobil bekas, memberi kesimpulan bahwa sistem penjualan berbasis web memberikan peluang baru, dimana dapat menampung jumlah mobil yang lebih banyak, transaksi penjualan secara digital, kemudahan masyarakat yang ingin menjual mobil cukup hanya mengupload foto dan spesifikasi mobil pada halam web perusahaan tanpa harus meletakan mobil merekadalam showroom mobil tersebut. Melalui mediaini dapat menghemat cukup banyak biaya operasional, harga jual mobil juga dapat menjadi lebih murah karena tidak ada biaya penampunya dan fee unutk perantara, memberikan keleluasaan pemilik mobil, area penjualan mejadi semakin fleksibeldan tidak terkendala pada lokasi dan tempatantara penjual dan pembeli. Berikut kerangkaberpikir yang penulis terapkan : 


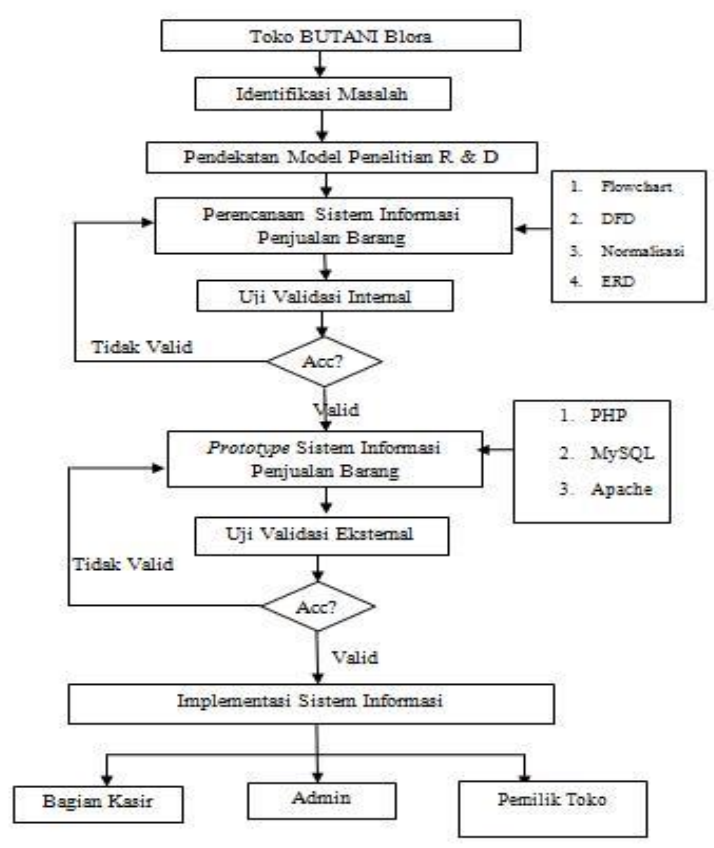

Sistem Informasi Penjualan pada TOKO

BUTANI Blora berbasis web

Hardisk $\quad: \quad 250 \mathrm{~GB}$

Monitor : 14 Inc

b) Unit Priter

2. Data master
a. Data User
b. Data Barang
c. Data Pelanggan
d. Data Supplier
e. Data Pembelian
f. Data Penjualan

3. Transaksi Penjualan
a. Form Barang
b. From Pelanggan
c. Form Supplier
d. Form Pembelian
e. Form Penjualan

2.4 Spesifikasi Produk

1. Software dan Hardware

A, Software

Perankat lunak yang digunakan untuk mendukung kinerja optimal penjualan barang berbasisweb pada Toko BUTANI Blora adalah :

1. MS Windows7

2. Aplikasi menggunakan XAMPP

3. Bahasa pemrogram PHP

4. Database MySQL

5. Webserver menggunakan APACHE

B.. Hardware

Perangkat lunak yang digunakan untuk mendukung kinerja optimal persedian barang dengan metode langsung pada Toko Butani Blora adalah :

Kebutuhan Hardware :

a) Unit komputer

$\begin{array}{lll}\text { CPU } & : & \text { Intel Celeron } \\ \text { Processor } & : & \text { C-847 }(1.10 \mathrm{GHz}) \\ \text { Memory } & : & \text { 2GB Gambar } 3.5 \\ \text { Dekomposisi } & & \end{array}$

4. Laporan yang dihasilkan
a. Laporan Stok Barang
b. Laporan Data Pelanggan
c. Laporan Data Supplier
d. Laporan Penjualan
e. Laporan Pembelian
f. Laporan Laba Rugi

3,1 Contex Diagram (CD)
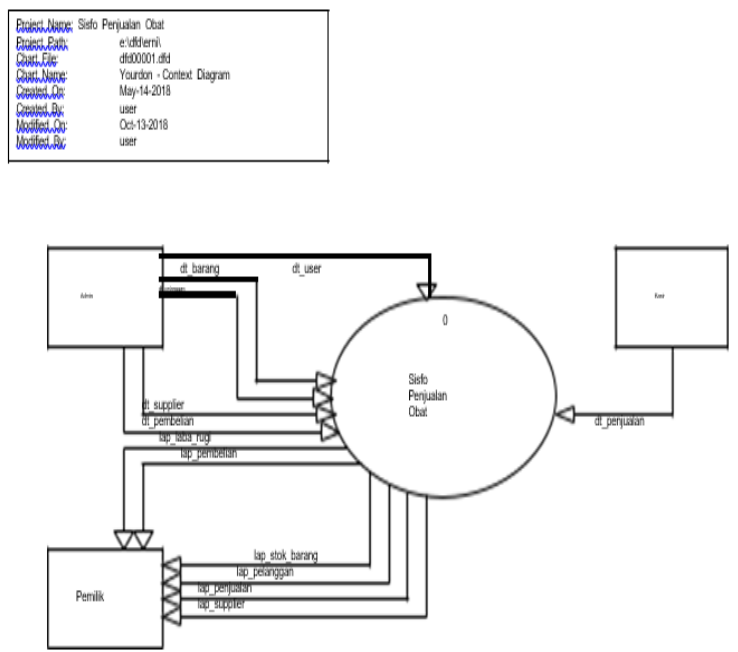

Gambar 3.4 Contex Diagram 
1. Decomposisi

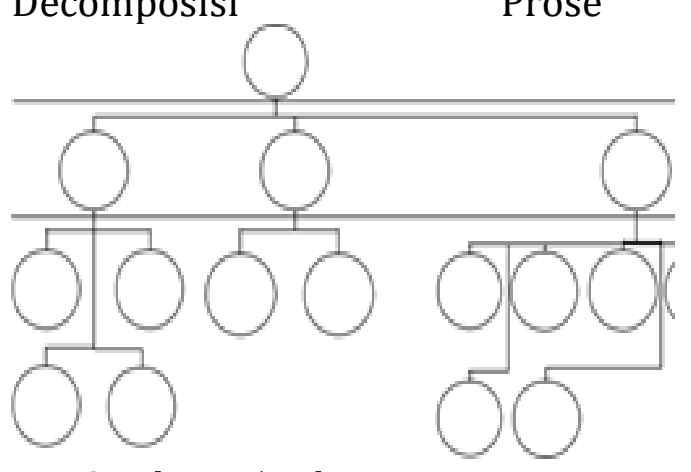

Gambar 3.5 Dekomposisi

Sistem Informasi Penjualan pada TOKO BUTANI Blora berbasis web

2. DFD Level 0

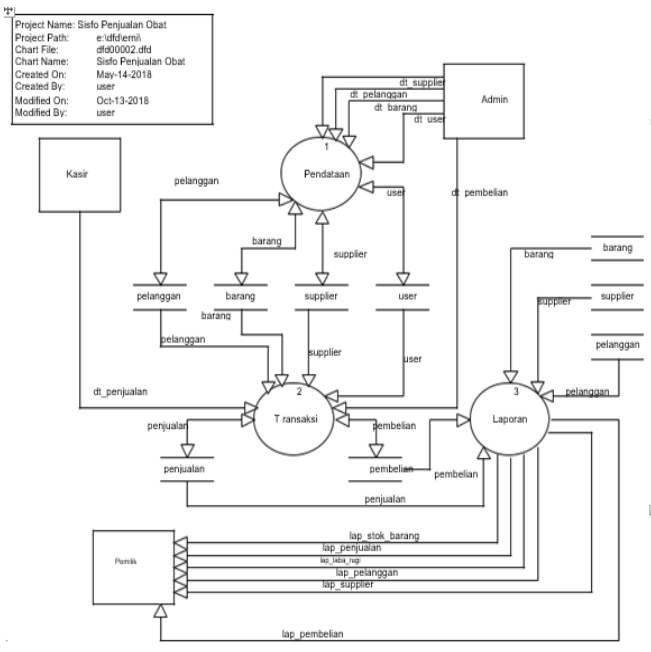

Gambar 3.6 DFD Level 1

3. DFD Level 1 Pendataan
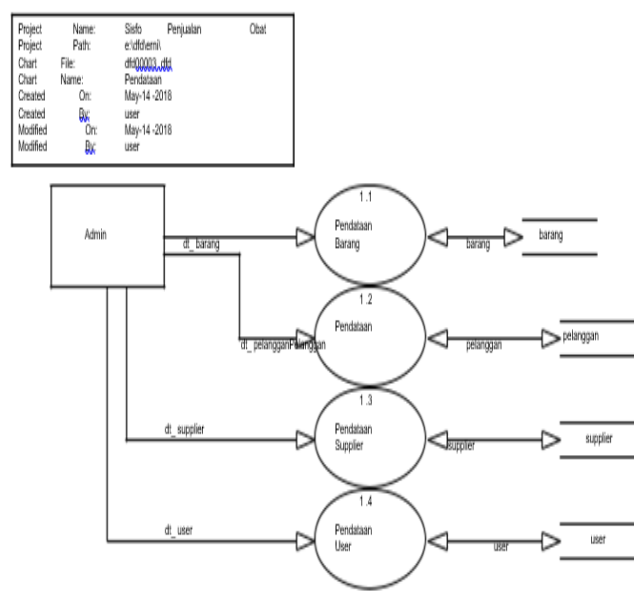

Gambar 3.6 DFD Level 1 Pendataan
4. DFD Level 1 Transaksi

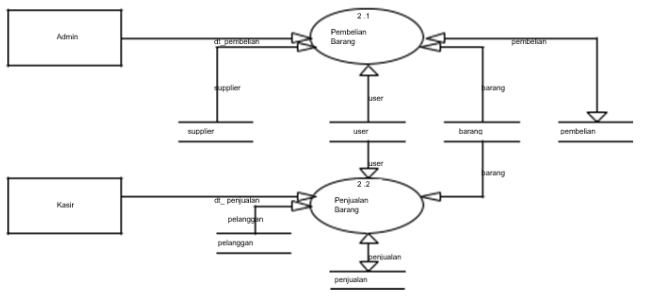

Gambar 3.6 DFD Level 1 Transaksi 5,, DFD Level 1 Laporan

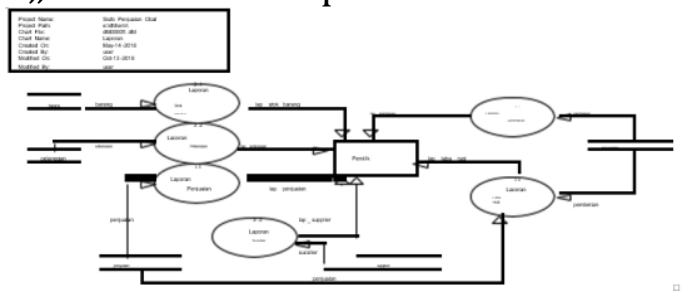

Gambar 3.7 DFD Level 1 Laporan

3.2 Normalisasi

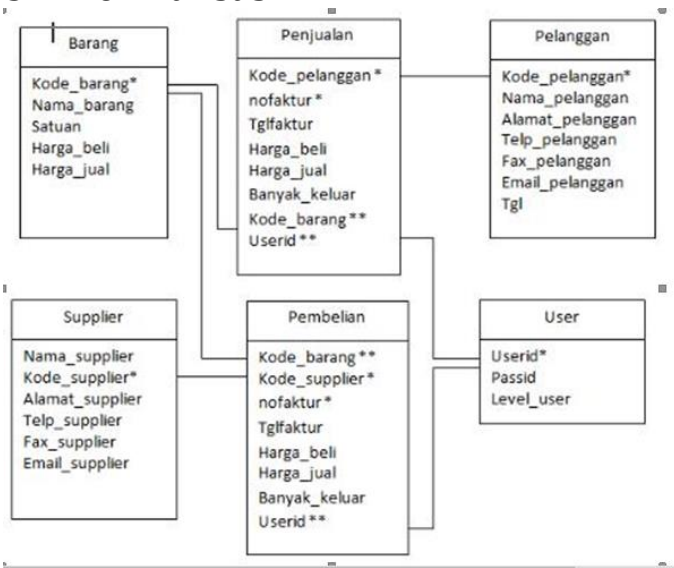

Gambar 3.8 Bentuk Normalisasi

3.3 Entity Relational Diagram (ERD)

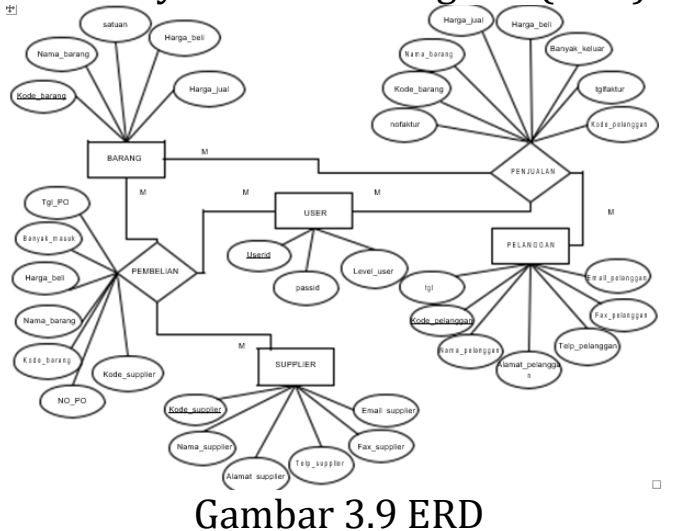


4.1 Hasil Pengembangan

a) Form laporan transaksi penjualan

b) Fungsi form menu laporan penjualan digunakan untuk

c) menampilkan laporan transaksi penjualan barang

d) kepada konsumen atau pelanggan.

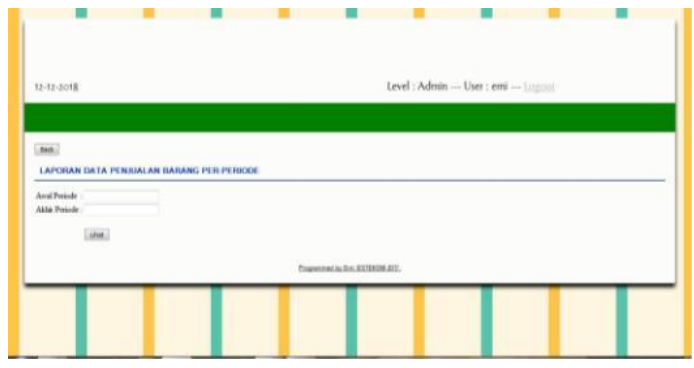

Gambar 4.16 Desain Form Menu Laporan Penjualan

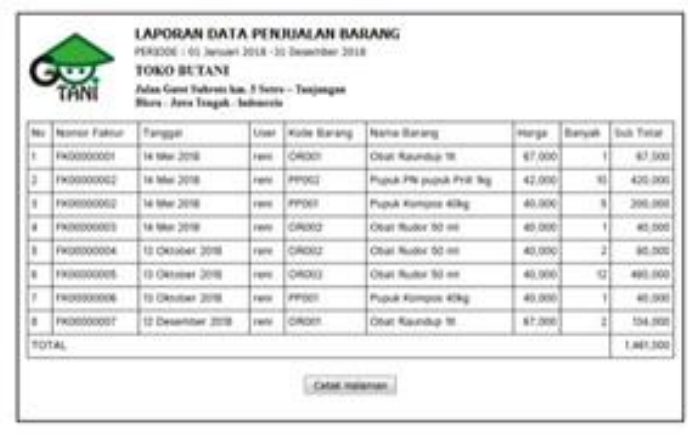

Gambar 4.17 Desain Tampilan Laporan Penjualan Barang

Form Menu Laporan Laba Rugi Fungsi form menu laporan laba rugi Digunakan untuk menampilkan penghasilan yang di peroleh pada toko.

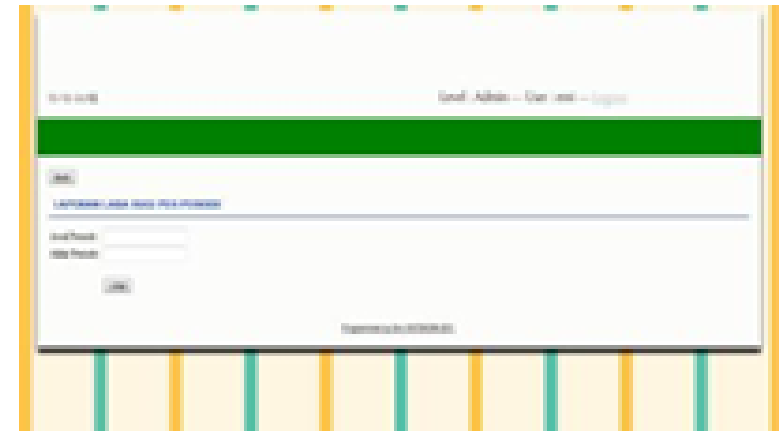

Gambar 4.18 Desain Form Menu Laporan Laba Rugi

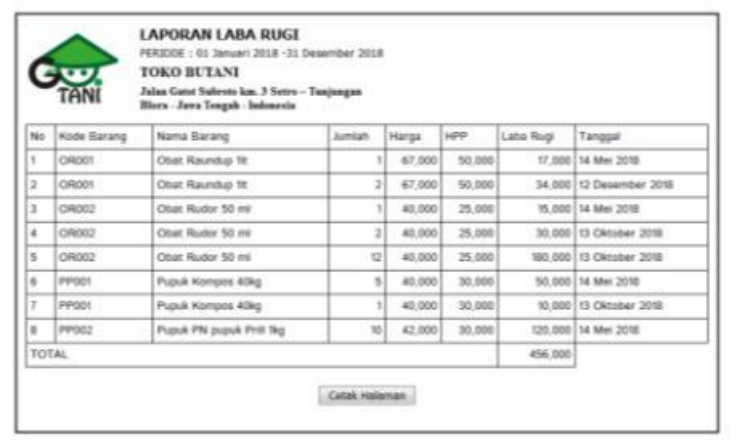

Gambar 4.19 Desain Tampilan Laporan Laba Rugi

\subsection{Kesimpulan}

Berdasarkan hasil penelitian dan pengembangan penyusunan skripsi dengan judul "Sistem Informasi Penjualan Obat Pertanian Berbasis Web pada Toko BUTANI Blora". Maka akan diketahuiadanya kesimpulan sebagai berikut :

a. Pembuatan aplikasi sistem Informasi penjualan obat pertanian berbasis web pada toko butani blora, sudah dapat mengurangi permasalahan yang ada pada toko obat pertanian BUTANI Blora, antara lain :

1. Mempermudah pencatatan transaksi penjualan di toko.

2. Memudahkan kasir untuk melakukan transaksi penjualan obat ditoko.dan 
mempermudah admin untuk membuat laporan stok barang, laporan data pelanggan, data supplier, laporan penjualan, laporan pembelian, dan laporan laba rugi, laporan tersimpan dan tersusun dengan baik, dan pemilik toko dapat melihat sewaktu-waktu laporan apabila dibutuhkan karena telah menggunakan sistem jaringan berbasis web tanpa harus memunta terhadap pihak admin.

3. Mempermudah mengontrol penjualan yang dilakukan oleh bagiankasir mempermudah pula mengontrol stok barang, dan dilengkapi dengan aplikasistokbatas

minimum,sehingga dapat

menghemat pengeluaran biaya untuk persediaan obat.

4. Sistem yang dibangun dapatmembantu karyawan mengelola penjualan obat dengan lebih mudah dan aman di toko obat BUTANI Blora, yang bisa di akses secara online atau berbasis web dan di lengkapi hak akses pada masing masing user.

b. Sistem yang dibagun dapat memberikan hak akses pada masing masing user atau pemakai. 


\section{REFERENCES}

Bahar, 2013; "Analisa dan Desain Sistem Informasi”, Yogyakarta : Bandung.

Chairul Marom, 2002; "Sistem Akuntansi Perusahaan Dagang", Edisi ke-dua, Jakarta : Grasindo.

Erhans A , 2002; "Membuat Desain Web DenganJAVASCRIPT", Jakarta :

Ercontara Rajawali.Fathansyah, 2002; "Basis Data”, Bandung : Informatika.

Gall dan Borg 1983:775; “Pengertian Pengembangan R \& D”, New York and London : Longman Inc.

Green, James Harry, 1985; “Local Area Network A User's Guide for Professionals”,

London : Scott, Foresman and Company. Hakim, Lukmanul dan Uus

Musalini, 2004; “Cara Cerdas Menguasai Layout”, Jakarta : PT Elex Media Komputindo.

Jogiyanto, 2003; “Analisis dan Desain Sistem”, Yogyakarta : CV Andi Offset.

Junaedi, Fajar, 2005; "Panduan Lengkap Pemrograman PHP untuk Membuat WEB Dinamis", Yogyakarta : PD. Anindya.

MeLeod Jr, Raymond, George PSchell, 2007; “Sistem InformasiManagemen”, Jakarta ～: Index.

Kadir, Abdul, 2002; "Dasar Pemrograman Web Dinamis Menggunakan PHP”, Yogyakarta: Andi Yogyakarta.

Mulyadi, 2008; Sistem Akuntansi, Edisi , Jakarta : Salemba EmpatNarko, 2008; "Sistem Akuntansi", Cetaan Kelima, Yogyakarta : Yayasan Pusaka Nusantara.

Nugroho, Bunafit, 2013; "Dasar Pemrograman Web PHP - MySQL dengan Dreamweaver" ,Yogyakarta : Gava Media.

Sandy Kosasi, 2016; "Perancangan Sistem Informasi Penjualan Berbasis Web Dalam Memasarkan Mobil Bekas”, ISSN : 2354-5771

Santoso, 2011; “Aplikasi Visual Basic 6.0 dan Visual Basic NET” ,Andi, Yogyakarta

Sugiyanto, 2013; "Sistem Informasi pada Butik Luwes Fashion Kecamatan Tulakan", Surakarta : Universitas Surakarta.

Sulhan, Mohammad, 2007; " Pengembangan Aplikasi Berbasis Web dengan PHP ASP”, Yogyakarta : Gava Media.

Tata Sutabri, 2012; "Analisis Sistem Informasi”, Andi, Yogyakarta

Winwin Yadiati dan IlhamWahyudi, 2006; "Pengantar Akuntansi”,Jakarta : Kencana PrenadaMedia Group.

Yohan Arum Widati, Rahajeng Ratananingsih, 2015;"Sistem InformasiPenjualan Dan PenilaianBatu Mulia Berbasis WebSentra Industri UD. SonyPermata Pacitan", ISSN :1693-590x 